
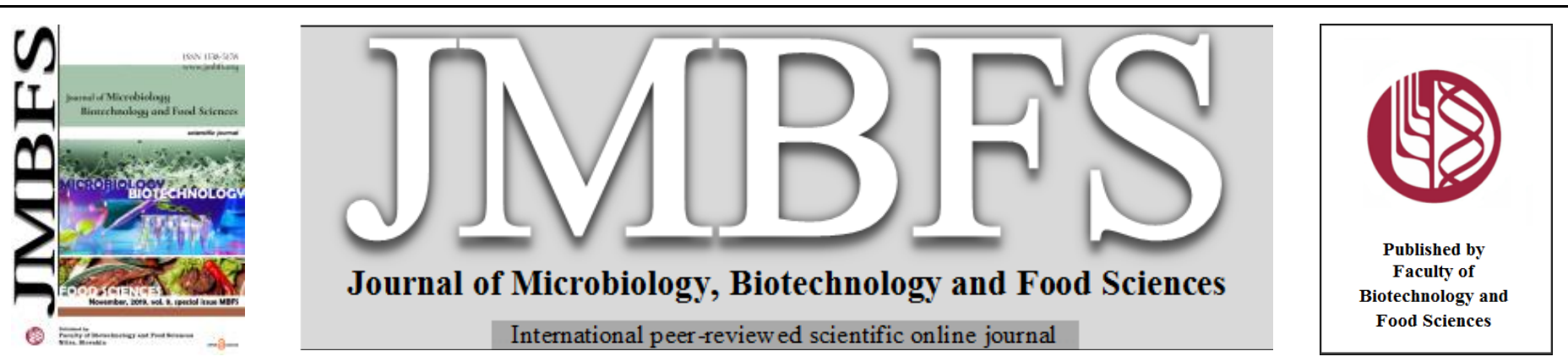

\title{
EVALUATION AND COMPARISON OF TOTAL POLYPHENOLS CONTENT AND ANTIOXIDANT ACTIVITY OF WILD GARLIC (ALLIUM URSINUM L.) IN SELECTED MORPHOLOGICAL PARTS
}

\author{
Ján Kovarovič*l, Judita Bystrická ${ }^{1}$, Dana Urminská ${ }^{2}$ Luboš Harangozo ${ }^{1}$, Alena Vollmannovál, Pavol Trebichalskýl, Mária \\ Timoracká ${ }^{1}$, Angel Antonio Carbonell-Barrachina ${ }^{3}$
}

Address(es): Ing. Ján Kovarovič,

${ }^{1}$ Slovak University of Agriculture in Nitra, Faculty of Biotechnology and Food Sciences, Department of Chemistry, Tr. A. Hlinku 2, 94976 Nitra, Slovakia.

${ }^{2}$ Slovak University of Agriculture in Nitra, Faculty of Biotechnology and Food Sciences, Department of Biochemistry and Biotechnology, Tr. A. Hlinku 2, 94976

Nitra, Slovakia.

${ }^{3}$ Universidad Miguel Hernández de Elche, Department Agro-food Technology, Avinguda de la Universitat d'Elx, s/n, 03202 Elx, Alacant, Spain.

*Corresponding author: xkovarovic@is.uniag.sk

doi: 10.15414/jmbfs.2019.9.special.492-495

\section{ARTICLE INFO}

Received 7. 8. 2019

Revised 8. 10. 2019

Accepted 30. 10. 2019

Published 8. 11. 2019

\section{Regular article}

open $\partial_{\text {ACCESS }}$

\begin{abstract}
Wild garlic (Allium ursinum L.) is a member of the Allium genus. However, wild garlic is still unexplored. To date, there are few publications that deal with this Allium species. The samples of plant material were collected from the three areas near Bratislava (Bratislava region), Krajné (Trenčin region) and Becherov (Prešov region). The aim of this study was to analyse the content of total polyphenols (TPC) and the value antioxidant activity (AOA) in selected morphological parts of wild garlic. The samples of wild garlic were homogenized and a methanolic extract was prepared. These extracts were used for analyses. Total polyphenol content in the samples ranged from $253.19 \pm 5.72 \mathrm{mg} \mathrm{GAE} . \mathrm{kg}^{-1} \mathrm{FW}$ (bulbs from area Becherov) to $1069.51 \pm 5.49 \mathrm{mg} \mathrm{GAE} . \mathrm{kg}^{-1} \mathrm{FW}$ (leaves from area Krajne). The values of antioxidant activity were from $2.54 \pm 0.83$ (bulbs from area Krajne) to $47.98 \pm 0.54 \%$ inhibition (leaves from area Bratislava).
\end{abstract}

Keywords: antioxidant activity, bulbs, flowers, leaves, polyphenols, wild garlic (Allium ursinum L.)

\section{INTRODUCTION}

Over the past few years, there has been growing interest in alternative plants, which can be a source of active compounds in the treatment and prevention of diseases such as metabolic cancer, stroke and coronary diseases (Lachowicz et al., 2018). The Allium genus includes hundreds of species, both wild and cultivated as vegetables or ornamentals. In the vegetable group, the frequently consumed species - onion (Allium cepa L.), garlic (Allium sativum L.), leek (Allium porrum L.), chives (Allium schoenoprasum L.), wild garlic (Allium ursinum L.), and garlic chives (Allium tuberosum L.) (Praticò et al., 2018) Peška et al. (2019) published that the Allium genus (Amaryllidaceae) includes more than 800 species, making it one of the largest monocotyledonous genera. It is also important to note that the species belonging to the Allium family have been used for a long time as a remedy for the prevention and treatment of certain diseases (Putnoky et al., 2013). Wild garlic (Allium ursinum L.) is a perennial plant, belonging to Allium genus, widespread through Europe and Asia, its leaves have been used for many centuries as edible and medicinal plants for its positive health properties. The health benefits of wild garlic have been attributed mainly to the sulphur-containing compounds like thiosulfinates and (poly) sulfides (among them allicin, disulfides and trisulfides), which are undoubtedly the most important constituents in terms of pharmacological activity (Tomšik et al., 2019). Krivokapic et al. (2019) published that numerous biologically active compounds are presented in this herb such as: sulphur compounds, phenolics, steroidal glycosides etc., however sulphur compounds mostly contribute to its pharmacological activity.

Plant polyphenols are aromatic hydroxylated compounds, commonly found in vegetables, fruits and many food sources. In the past few years, polyphenols have gained much more attention and have become an important focus of research interest, owing to their antioxidant activities and various beneficial effects on human health, such as antioxidant, antimutagenic and anticargionogenic effects, as well as their ability to modify gene expression (Kılıçü̈n and Altıner, 2010). Antioxidants are compounds that, in low concentration, can prevent biomolecules from undergoing oxidative damage through free radical mediated reactions (Bendary et al., 2013).

The wild garlic (Allium ursinum L.) is relatively unknown with respect to its content of total polyphenols and antioxidant activity in selected parts of wild garlic. The aim of the present study was to determine the content of polyphenols and antioxidant activity in selected parts of wild garlic (bulbs, leaves and flowers). Our hypothesis is that different parts of the wild garlic have different content of total polyphenols and values of antioxidant activity. We expects the positive correlation between antioxidant activity values and total polyphenols content in this experiment in the selected parts of wild garlic.

\section{MATERIAL AND METHODS}

\section{Plant material}

The material used in this study comprised leaves, flowers nad bulbs of wild garlic (Allium ursinum L.). Wild garlic plants were obtained in April 2018, from three different a forest areas near Bratislava (Bratislava region), Krajné (Trenčin region) and Becherov (Prešov region). In April, 50 wild garlic plants were collected, and morphological parts of plants were separated - leaves, flowers and bulbs. All plant samples were free of external damage and fresh leaves, flowers and bulbs of wild garlic were hand selected and used freshly for methanolic extracts preparation. The samples of plant material were analyzed individually by selected methods, and were used in fresh material on analysis.

\section{The local climate conditions}

This study was performed in three selected areas: Bratislava (Bratislava region), Krajné (Trenčin region) and Becherov (Prešov region). Bratislava is situated on the western Slovakia. It belongs to warmer areas in Slovakia. The average annual rainfall is $527 \mathrm{~mm}$ and the average annual temperature is $9.9^{\circ} \mathrm{C}$. Agrochemical characteristic of soil from Bratislava is shown in the Table 1. Krajné is situated on the northwestern Slovakia. It belongs to slightly warmer areas in Slovakia. The average annual rainfall is $615 \mathrm{~mm}$ and the average annual temperature is 8.7 ${ }^{\circ} \mathrm{C}$. Agrochemical characteristic of soil from Krajne is shown in the Table 2. Becherov is situated on the northeastern Slovakia. It belongs to colder areas in Slovakia. The average annual rainfall is $725 \mathrm{~mm}$ and the average annual temperature is $6.1^{\circ} \mathrm{C}$. Agrochemical characteristic of soil from Becherov is shown in the Table 3. 
Table 1 Agrochemical characteristic of soil substrate in mg. $\mathrm{kg}^{-1}$ from area Bratislava

\begin{tabular}{|c|c|c|c|c|c|c|c|c|c|}
\hline \multirow[t]{2}{*}{$\begin{array}{l}\text { Agrochemical } \\
\text { characteristic }\end{array}$} & $\begin{array}{c}\mathbf{p H} \\
\left(\mathrm{H}_{2} \mathrm{O}\right) \\
\end{array}$ & $\begin{array}{l}\mathbf{p H} \\
(\mathrm{KCl})\end{array}$ & $\begin{array}{l}\text { Cox } \\
(\%)\end{array}$ & $\begin{array}{c}\text { Humus } \\
(\%)\end{array}$ & & & & & \\
\hline & 5.89 & 5.03 & 1.42 & 2.45 & & & & & \\
\hline \multirow[t]{2}{*}{ Nutrients } & $\mathbf{K}$ & $\mathbf{C a}$ & Mg & $\mathbf{P}$ & & & & & \\
\hline & 99.70 & 965.80 & 169.00 & 22.90 & & & & & \\
\hline Heavy metals & $\mathbf{Z n}$ & $\mathbf{C u}$ & Mn & $\mathrm{Fe}$ & $\mathrm{Cr}$ & Cd & $\mathbf{P b}$ & Co & $\mathbf{N i}$ \\
\hline Aqua regia & 41.00 & 16.20 & 586.60 & 17614 & 16.50 & 1.62 & 38.80 & 8.70 & 23.50 \\
\hline Limit value* & 100.0 & 60.0 & - & - & 70.0 & 0.4 & 70.0 & 15.0 & 40.0 \\
\hline $\begin{array}{l}\mathrm{NH}_{4} \mathrm{NO}_{3} \\
\left(\mathrm{c}=1 \mathrm{~mol} \cdot \mathrm{dm}^{-3}\right)\end{array}$ & 0.27 & 0.04 & 4.20 & 0.32 & 0.03 & 0.118 & 0.16 & 0.10 & 0.22 \\
\hline Critical value $* *$ & 2.0 & 1.0 & - & - & - & 0.1 & 0.1 & - & 1.5 \\
\hline
\end{tabular}

Legend: *Limit value for Aqua regia- Law no. 220/2004

**Critical value for $\mathrm{NH}_{4} \mathrm{NO}_{3}\left(\mathrm{c}=1\right.$ mol.dm $\left.{ }^{-3}\right)$ - Law no. $220 / 2004$

Table 2 Agrochemical characteristic of soil substrate in mg. $\mathrm{kg}^{-1}$ from area Krajne

\begin{tabular}{|c|c|c|c|c|c|c|c|c|c|}
\hline \multirow{2}{*}{$\begin{array}{l}\text { Agrochemical } \\
\text { characteristic }\end{array}$} & $\begin{array}{c}\mathbf{p H} \\
\left(\mathbf{H}_{2} \mathrm{O}\right)\end{array}$ & $\begin{array}{c}\text { pH } \\
(\mathrm{KCl})\end{array}$ & $\begin{array}{l}\text { Cox } \\
(\%)\end{array}$ & $\begin{array}{c}\text { Humus } \\
(\%)\end{array}$ & & & & & \\
\hline & 7.62 & 6.96 & 1.59 & 2.56 & & & & & \\
\hline \multirow{2}{*}{ Nutrients } & $\mathbf{K}$ & $\mathrm{Ca}$ & Mg & $\mathbf{P}$ & & & & & \\
\hline & 257.70 & 3184.90 & 238.50 & 69.20 & & & & & \\
\hline Heavy metals & $\mathbf{Z n}$ & $\mathbf{C u}$ & Mn & $\mathbf{F e}$ & $\mathrm{Cr}$ & Cd & $\mathbf{P b}$ & Co & $\mathbf{N i}$ \\
\hline Aqua regia & 48.90 & 17.50 & 752.50 & 19749 & 25.30 & 2.19 & 37.40 & 11.50 & 35.00 \\
\hline Limit value* & 100.0 & 60.0 & - & - & 70.0 & 0.4 & 70.0 & 15.0 & 40.0 \\
\hline $\begin{array}{l}\mathrm{NH}_{4} \mathrm{NO}_{3} \\
\left(\mathrm{c}=1 \mathrm{~mol} \cdot \mathrm{dm}^{-3}\right)\end{array}$ & 0.03 & 0.07 & 1.08 & 0.30 & 0.12 & 0.164 & 0.26 & 0.16 & 0.22 \\
\hline Critical value ${ }^{* *}$ & 2.0 & 1.0 & - & - & - & 0.1 & 0.1 & - & 1.5 \\
\hline
\end{tabular}

Legend: *Limit value for Aqua regia- Law no. 220/2004

** Critical value for $\mathrm{NH}_{4} \mathrm{NO}_{3}\left(\mathrm{c}=1\right.$ mol.dm $\left.{ }^{-3}\right)$ - Law no. 220/2004

Table 3 Agrochemical characteristic of soil substrate in $\mathrm{mg}^{\mathrm{kg}} \mathrm{kg}^{-1}$ from area Becherov

\begin{tabular}{|c|c|c|c|c|c|c|c|c|c|}
\hline \multirow{2}{*}{$\begin{array}{l}\text { Agrochemical } \\
\text { characteristic }\end{array}$} & $\begin{array}{c}\mathrm{pH} \\
\left(\mathrm{H}_{2} \mathrm{O}\right)\end{array}$ & $\begin{array}{c}\mathbf{p H} \\
(\mathrm{KCl})\end{array}$ & $\begin{array}{l}\text { Cox } \\
(\%)\end{array}$ & $\begin{array}{c}\text { Humus } \\
(\%)\end{array}$ & & & & & \\
\hline & 7.04 & 6.23 & 1.82 & 3.14 & & & & & \\
\hline \multirow{2}{*}{ Nutrients } & $\mathbf{K}$ & $\mathrm{Ca}$ & Mg & $\mathbf{P}$ & & & & & \\
\hline & 142.10 & 2841.90 & 198.90 & 9.20 & & & & & \\
\hline Heavy metals & $\mathbf{Z n}$ & $\mathbf{C u}$ & Mn & $\mathrm{Fe}$ & $\mathrm{Cr}$ & Cd & $\mathbf{P b}$ & Co & $\mathbf{N i}$ \\
\hline Aqua regia & 47.10 & 22.50 & 1157.70 & 25794 & 47.40 & 2.19 & 35.15 & 15.50 & 91.10 \\
\hline Limit value* & 100.0 & 60.0 & - & - & 70.0 & 0.4 & 70.0 & 15.0 & 40.0 \\
\hline $\begin{array}{l}\mathrm{NH}_{4} \mathrm{NO}_{3} \\
\left(\mathrm{c}=1 \mathrm{~mol} \cdot \mathrm{dm}^{-3}\right)\end{array}$ & 0.04 & 0.06 & 2.42 & 0.31 & 0.15 & 0.18 & 0.27 & 0.16 & 0.26 \\
\hline Critical value ${ }^{* *}$ & 2.0 & 1.0 & - & - & - & 0.1 & 0.1 & - & 1.5 \\
\hline
\end{tabular}

Legend: *Limit value for Aqua regia- Law no. 220/2004

$* *$ Critical value for $\mathrm{NH}_{4} \mathrm{NO}_{3}\left(\mathrm{c}=1\right.$ mol.dm $\left.{ }^{-3}\right)$ - Law no. $220 / 2004$

\section{Chemicals and extraction}

High-purity chemical reagents were used for all operations. Folin-Ciocalteu assay and gallic acid were purchased from Merck, Darmstadt, Germany. Sodium carbonate, methanol and 2,2-diphenyl-1-picrylhydrazyl radical (DPPH') were obtained from Sigma-Aldrich (St. Louis, Missouri, USA). The plants of wild garlic were divided into three parts: leaves, flowers and bulbs. The fresh leaves, flowers and bulbs of wild garlic were homogenized in the mixer (Kinematica AG, Luzern, Switzerland). Methanol extracts were prepared by adding $50 \mathrm{ml}$ of $80 \%$ methanol to $25 \mathrm{~g}$ milled sample and extracting in the shaker (Shaker GFL $3006,125 \mathrm{rpm})$ for $12 \mathrm{~h}$. Samples were then filtered through filter paper (130 g.m ${ }^{-2}$, Filtrak, Thermalbad Wiesenbad, Germany) and kept at $8{ }^{\circ} \mathrm{C}$ for further analysis. Each determination was carried out in six replications.

\section{Spectrophotometric determination of total polyphenols (TPC)}

Total polyphenols were determined by the method of Lachman $\boldsymbol{e t}$ al. (2003) and expressed as milligrams of gallic acid equivalent per kilogram (mg GAE. $\mathrm{kg}^{-1}$ ) fresh weight (FW). Gallic acid is usually used as a standard unit for phenolics content determination because a wide spectrum of phenolic compounds. The total polyphenol content was estimated using Folin-Ciocalteau assay. The FolinCiocalteau (Merck) phenol reagent was added to a volumetric flask containing $100 \mathrm{ml}$ of extract of wild garlic samples. The content was mixed and $5 \mathrm{ml}$ of a sodium carbonate solution by Merck $(20 \%)$ was added after $3 \mathrm{~min}$. The volume was adjusted to $50 \mathrm{ml}$ by adding of distilled water. After two hours the absorbance was measured at $765 \mathrm{~nm}$ (Spectrophotometer Shimadzu UV-1800; Shimadzu, Kyoto, Japan) of wavelength against blank. The concentration of polyphenols was calculated from a standard curve plotted with known concentration of gallic acid.

\section{Spectrophotometric determination of antioxidant activity (AOA)}

Antioxidant activity was measured by the Brand-Williams $\boldsymbol{e t}$ al. (1995) methodusing a compound DPPH $^{\circ}$ (2.2-diphenyl-1-pikrylhydrazyl). 2.2-diphenyl-1pikrylhydrazyl (DPPH') was pipetted to cuvette $\left(3.9 \mathrm{~cm}^{3}\right)$ then the value of absorbance, which corresponded to the initial concentration of $\mathrm{DPPH}^{*}$ solution in time $\mathrm{A}_{0}$ was written. Then $0.1 \mathrm{~cm}^{3}$ of the followed solution was added and then the dependence $A=f(t)$ was immediately started to measure. The absorbance of 10 minutes at $515.6 \mathrm{~nm}$ in the spectrophotometer (Shimadzu UV - 1800 , Shimadzu, Kyoto, Japan) was mixed and measured $\left(\mathrm{A}_{\mathrm{t}}\right)$. The percentage of inhibition reflects how antioxidant compound are able to remove $\mathrm{DPPH}^{-}$radical at the given time.

Computation: Inhibition $(\%)=\left(\mathrm{A}_{0}-\mathrm{A}_{\mathrm{t}} / \mathrm{A}_{0}\right) \times 100$

\section{Statistical analysis}

Results were statistically evaluated by the Analysis of Variance. All the assays were carried out in quadruplicates and results are expressed as mean \pm SD. The data were subjected to the F-test in the one-way analysis of variance (ANOVA) If the $p$-value of the F-test is less than 0.05 , there is a statistically significant difference between the at the $95 \%$ confidence level; the Multiple Range Tests will tell which means are significantly different from which others. The method currently being used to discriminate among the means of Fisher's least significant difference (LSD) procedure. Using statistical software Statgraphics Centurion XVI.I (Statpoint Technologies, The Plains, Virginia, USA) and a correlation analysis (Microsoft Excel, Washington, USA) was used. 


\section{RESULTS AND DISCUSSION}

In this study the content of polyphenols and antioxidant activity (\% inhibition) in selected parts (leaves, flowers and bulbs) of wild garlic in the three areas were tested and evaluated. The results of antioxidant activity value and the content of total polyphenols in selected samples of wild garlic are summarized in Table 4 and Table 5.

Table 4 The average contents of total polyphenols (mg GAE. $\mathrm{kg}^{-1} \mathrm{FW}$ ) in selected morphological parts of wild garlic

\begin{tabular}{lccc}
\hline \multirow{2}{*}{ Area } & \multicolumn{3}{c}{ Part of plants } \\
& Leaves & Flowers & Bulbs \\
\hline Bratislava & $851.18 \pm 11.39^{\mathrm{c}}$ & $435.05 \pm 7.86^{\mathrm{b}}$ & $283.51 \pm 7.62^{\mathrm{a}}$ \\
Krajne & $1069.51 \pm 5.49^{\mathrm{c}}$ & $668.21 \pm 6.56^{\mathrm{b}}$ & $274.81 \pm 8.57^{\mathrm{a}}$ \\
Becherov & $642.95 \pm 3.52^{\mathrm{c}}$ & $554.54 \pm 8.50^{\mathrm{b}}$ & $253.19 \pm 5.72^{\mathrm{a}}$
\end{tabular}

Note: ${ }^{\text {a-c }}$ values with different letters mean significant differences $(p<0.05)$ among selected morphological parts of wild garlic; contents of total polyphenols are expressed as arithmetic mean

Table 5 The average values of antioxidant activity (\% inhibition) in selected selected morphological parts of wild garlic

\begin{tabular}{lccc}
\hline \multirow{2}{*}{ Area } & \multicolumn{3}{c}{ Part of plants } \\
& Leaves & Flowers & Bulbs \\
\hline Bratislava & $40,20 \pm 0,57^{\mathrm{c}}$ & $22,21 \pm 0,74^{\mathrm{b}}$ & $14,58 \pm 1,63^{\mathrm{a}}$ \\
Krajne & $47,98 \pm 0,54^{\mathrm{c}}$ & $37,17 \pm 1,05^{\mathrm{b}}$ & $2,54 \pm 0,83^{\mathrm{a}}$ \\
Becherov & $35,71 \pm 0,45^{\mathrm{c}}$ & $16,15 \pm 1,10^{\mathrm{b}}$ & $4,90 \pm 0,69^{\mathrm{a}}$ \\
\hline N $^{\mathrm{a}-\mathrm{c}}$ &
\end{tabular}

Note: ${ }^{\text {a-c }}$ values with different letters mean significant differences $(p<0.05)$ among selected morphological parts of wild garlic; values of antioxidant activity are expressed as arithmetic mean

The content of total polyphenols in selected samples parts (leaves, flowers and bulbs) of wild garlic ranges from $253.19 \pm 5.72 \mathrm{mg} \mathrm{GAE} . \mathrm{kg}^{-1} \mathrm{FW}$ (bulbs) to $1069.51 \pm 5.49 \mathrm{mg} \mathrm{GAE} . \mathrm{kg}^{-1} \mathrm{FW}$ (leaves).

Based on the measured content of total polyphenols in selected parts of wild garlic can be in the ensuing order: leaves > flowers > bulbs in all three areas. In leaves of wild garlic from area Bratislava average content of total polyphenols is 3.01-times higher than in bulbs of wild garlic from area Bratislava. Also, in leaves of wild garlic from area Krajne average content of total polyphenols is 3.89-times higher than in bulbs of wild garlic from area Krajne and in leaves of wild garlic from area Becherov average content of total polyphenols is 2.54-times higher than in bulbs of wild garlic from area Becherov.

Lachowicz et al. (2016) published that the content of total polyphenols varied from $65 \mathrm{mg} . \mathrm{kg}^{-1} \mathrm{FW}$ in wild garlic bulbs to $425 \mathrm{mg} . \mathrm{kg}^{-1} \mathrm{FW}$ in wild garlic leaves In comparison to our determined values of polyphenols their results were in similar interval. Our results are higher compared to Alexieva et al. (2014) who has published that the content of total polyphenols is $400 \mathrm{mg} \cdot \mathrm{kg}^{-1} \mathrm{FW}$ in the wild garlic leaves. Our results are in correspondence with the results of Toth et al. (2018) who indicated the content of polyphenols in wild garlic leaves from $726 \pm$ $10.1 \mathrm{mg}$ GAE. $\mathrm{kg}^{-1} \mathrm{FW}$ to $827 \pm 9.82 \mathrm{mg} \mathrm{GAE} \cdot \mathrm{kg}^{-1} \mathrm{FW}$ and Lenkova $\boldsymbol{e t}$ al. (2016) who indicated the content of polyphenols in wild garlic leaves $871 \pm 8.16$ mg.kg-1 FW. Statistically significant highest content of total polyphenols ( $p$ $<0.05)$ was recorded in wild garlic leaves in the all areas. Statistically significan the lowest content of total polyphenols $(p<0.05)$ was recorded in wild garlic bulbs in the all areas.

Another indicator that has been evaluated and compared was the antioxidant activity of selected morphological parts of wild garlic. The values of antioxidant activity were in interval from $2.54 \pm 0.83 \%$ inhibition wild garlic bulb to $47.98 \pm$ $0.54 \%$ inhibition wild garlic leaves. Based on the measured values of antioxidant activity in selected morphological parts of wild garlic (leaves, flowers and bulbs) can be in the ensuing order: leaves > flowers > bulbs. Sahnoun et al. (2017) determines in his study higher values, in comparison with our results in wild garlic bulbs. Their values were in interval from $41.81 \%$ inhibition (wild garlic leaves) to $66.61 \%$ inhibition (wild garlic bulbs). Toth et al. (2018) reported that the value of antioxidant activity was recorded in wild garlic leaves in the interval from $10.7 \pm 1.57 \%$ inhibition to $17.3 \pm 0.85 \%$ inhibition. In comparison to our determined values of antioxidant their results were in similar interval. Our results are lower compared to Bârlă et al. (2017), who has published that the value of antioxidant activity is $77.9 \%$ inhibition in the wild garlic. Our results are in correspondence with the results of Lenkova et al. (2016) who indicated the value of antioxidant activity in wild garlic $45.34 \pm 0.62 \%$ inhibition.

In this study we have found also positive relation between the content of tota polyphenols and antioxidant activity in leaves, flowers and bulbs of wild garlic ( $\mathrm{r}$ $=0.892, r=0.875, r=843$ ). To date, there are very few studies that deal with the relation between content of total polyphenols and antioxidant activity in wild garlic. Results are shown in Figure 1, Figure 2 and Figure 3. These results are in good accordance with Wojdyło et al. (2007), who reported a positive correlation between total antioxidant activity and total phenolic content. Terpinc et al. (2012) published that no significant correlation could be found between the total phenolic content and antioxidant activity of various plant extracts.

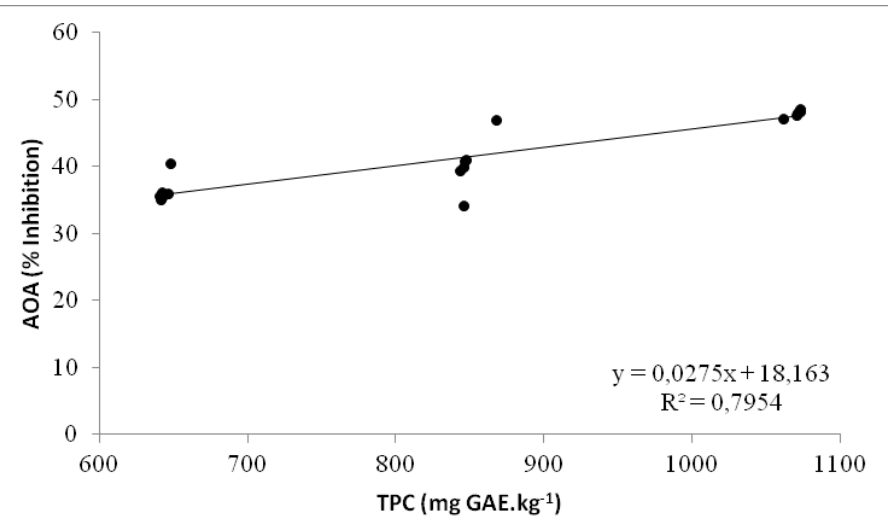

Figure 1 Relation between antioxidant activity (AOA) and total polyphenols content (TPC) in wild garlic leaves

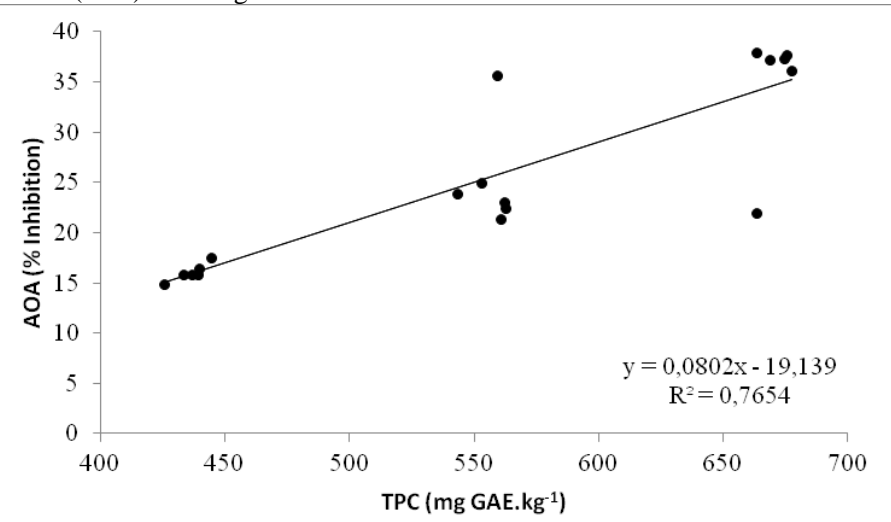

Figure 2 Relation between antioxidant activity (AOA) and total polyphenols content (TPC) in wild garlic flowers

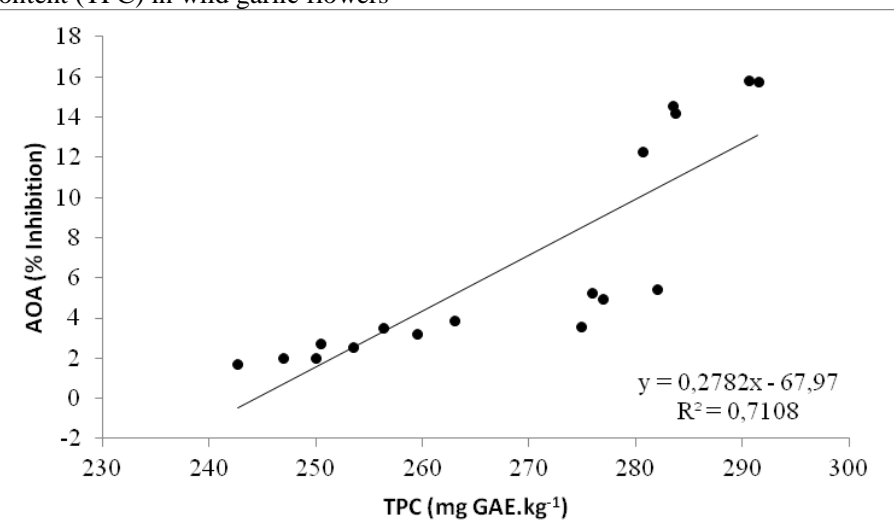

Figure 3 Relation between antioxidant activity (AOA) and total polyphenols content (TPC) in wild garlic bulbs

\section{CONCLUSION}

Wild garlic (Allium ursinum L.) is a widespread plant in Europe that grows predominantly in forests and near rivers. To date, there are few studies dealing with the bioactive substance of wild garlic. The results suggest that wild garlic leaves showed higher content of polyphenols and antioxidant activity than the wild garlic flowers and bulbs in this study. Total polyphenol content in the samples ranged from $253.19 \pm 5.72 \mathrm{mg}$ GAE. $\mathrm{kg}^{-1} \mathrm{FW}$ (bulbs from area Becherov) to $1069.51 \pm 5.49 \mathrm{mg} \mathrm{GAE} . \mathrm{kg}^{-1} \mathrm{FW}$ (leaves from area Krajne). The values of antioxidant activity were from $2.54 \pm 0.83$ (bulbs from area Krajne) to $47.98 \pm 0.54 \%$ inhibition (leaves from area Bratislava). In this study we have found also positive relation between the content of total polyphenols and antioxidant activity in selected morphological parts of wild garlic (Allium ursinum L.): bulbs, leaves and flowers.. It is also important to note that the results of the present study require further experiments such as determination of phenolic acids, flavonoids, sulphur compounds and macroelements content in wild garlic.

Acknowledgments: This work was supported by scientific grant VEGA 1/0139/17, VEGA 1/0114/18, KEGA 011SPU-4/2017. 


\section{REFERENCES}

Act No. 220/2004 Coll. Of Laws of Slovak Republic. On the conservation and use of agricul- tural land, amending the Act No. 245/2003 Coll. on integrated pollution prevention and control, amending and supplementing of certain acts, as amended.

ALEXIEVA, J., MIHAYLOVA, D., POPOVA, A. 2014. Antioxidant capacity and thin layer chromatography of ethanol extracts of Allium ursinum L. and Allium bulgaricum L. Scientific Bulletin. Series F. Biotechnologies, 18, 91-96. ISSN 2285-1364.

BÂRLĂ, G. F., POROCH-SERIŢAN, M., SĂNDULEAC, E., CIORNEI, S. E. 2016. Antioxidant activity and total phenolic content in Allium ursinum and Ranunculus Ficaria. Food and Environment Safety Journal, 13(4). 349-353. http://www.fia.usv.ro/fiajournal/index.php/FENS/article/viewFile/123/121.

BRAND-WILLIAMS, W., CUVELIER, M. E., BERSET, C. L. W. T. 1995. Use of a free radical method to evaluate antioxidant activity. LWT-Food science and Technology, 28(1), 25-30. http://dx.doi.org/10.1016/S0023-6438(95)80008-5.

BENDARY, E., FRANCIS, R. R., ALI, H. M. G., SARWAT, M. I., EL HADY, S. 2013. Antioxidant and structure-activity relationships (SARs) of some phenolic and anilines compounds. Annals of Agricultural Sciences, 58(2), 173 181. https://doi.org/10.1016/j.aoas.2013.07.002.

KILIÇGÜN, H., ALTINER, D. 2010. Correlation between antioxidant effect mechanisms and polyphenol content of Rosa canina. Pharmacognosy magazine, 6(23), 238. https://doi.org/10.4103/0973-1296.66943.

KRIVOKAPIC, M., BRADIC, J., PETKOVIC, A., POPOVIC, M. 2018 Phytochemical and Pharmacological Properties of Allium Ursinum. Serbian Journal of Experimental and Clinical Research, 1(1), https://doi.org/10.2478/SJECR-2018-0003.

LACHMAN, J., PRONEK, D., HEJTMANKOVA, A., DUDJAK, J., PIVEC, V., FAITOVÁ, K. 2003. Total polyphenol and main flavonoid antioxidants in different onion (Allium cepa L.) varieties. Horticultural science, 30(4), 142-147. https://doi.org/10.17221/3876-HORTSCI.

LACHOWICZ, S., KOLNIAK-OSTEK, J., OSZMIAŃSKI, J., WIŚNIEWSKI, R. 2017. Comparison of phenolic content and antioxidant capacity of bear garlic (Allium ursinum L.) in different maturity stages. Journal of food processing and preservation, 41(1), e12921. https://doi.org/10.1111/jfpp.12921.

LACHOWICZ, S., OSZMIAŃSKI, J., WIŚNIEWSKI, R. 2018. Determination of triterpenoids, carotenoids, chlorophylls, and antioxidant capacity in Allium ursinum L. at different times of harvesting and anatomical parts. European Food Research and Technology, 244(7), 1269-1280. https://doi.org/10.1007/s00217018-3042-3.

LENKOVA, M., BYSTRICKÁ, J., TÓTH, T., HRSTKOVA, M. 2016 Evaluation and comparison of the content of total polyphenols and antioxidant activity of selected species of the genus Allium. Journal of Central European Agriculture, 17(4), 1119-1133. http://dx.doi.org/10.5513/JCEA01/17.4.1820.

PEŠKA, V., MANDÁKOVÁ, T., IHRADSKÁ, V., FAJKUS, J. 2019 Comparative Dissection of Three Giant Genomes: Allium cepa, Allium sativum, and Allium ursinum. International journal of molecular sciences, 20(3), 733. https://doi.org/10.3390/ijms20030733.

PRATICÒ, G., GAO, Q., MANACH, C., DRAGSTED, L. O. 2018. Biomarkers of food intake for Allium vegetables. Genes \& nutrition, 13(1), 34 https://doi.org/10.1186/s12263-018-0624-4.

PUTNOKY, S., CAUNII, A., BUTNARIU, M. 2013. Study on the stability and antioxidant effect of the Allium ursinum watery extract. Chemistry Central Journal, 7(1), 21. https://doi.org/10.1186/1752-153X-7-21.

SAHNOUN, D., KSOURI, W. M., YOUNES, I., HAMMAMI, M., BETTAIEB, I., SAADA, M., MKADMINI, K., KSOURI, R.,SERAIRI, R. B. 2017. Antioxidant activity and biochemical composition of fresh bulbs and leaves of wild garlic Allium ursinum. Journal of New Sciences, 44, 2392-2399. ISSN 2286-5314.

TERPINC, P., ČEH, B., ULRIH, N. P., ABRAMOVIČ, H. 2012. Studies of the correlation between antioxidant properties and the total phenolic content of different oil cake extracts. Industrial crops and products, 39, 210-217. https://doi.org/10.1016/j.indcrop.2012.02.023.

TOMŠIK, A. ŠARIĆ, L., BERTONI, S., PROTTI, M., ALBERTINI, B. MERCOLINI, L., PASSERINI, N. 2019. Encapsulations of wild garlic (Allium ursinum L.) extract using spray congealing technology. Food Research International, 119, 941-950. https://doi.org/10.1016/j.foodres.2018.10.081. TÓTH, T., KOVAROVIČ, J., BYSTRICKÁ, J., VOLLMANNOVÁ, A., MUSILOVÁ, J., LENKOVÁ, M. 2018. The content of polyphenols and antioxidant activity in leaves and flowers of wild garlic (Allium ursinum L.). Acta Alimentaria, 47(2), 252-258. https://doi.org/10.1556/066.2018.47.2.15.

WOJDYŁO, A., OSZMIAŃSKI, J., CZEMERYS, R. 2007. Antioxidant activity and phenolic compounds in 32 selected herbs. Food chemistry, 105(3), 940-949 https://doi.org/10.1016/j.foodchem.2007.04.038. 